DOI: $10.21802 / \mathrm{artm} .2021 .2 .18 .165$.

UDC 378.147.227

\title{
FORMATION AND EVALUATION FEATURES OF CLINICAL THINKING IN DISTANCE LEARNING STUDENTS
}

\author{
T.B. Snizhko ${ }^{1}$, V.D. Vorobiy ${ }^{1}$, S.S. Snizhko ${ }^{2}$, I.K. Churpiy $^{3}$, L.Ya. Shpilchak ${ }^{4}$ \\ Ivano-Frankivsk National Medical University: \\ ${ }^{1}$ Department of Obstetrics and Gynecology named after ID. Lanovyj, \\ ${ }^{2}$ Department of Surgery and Cardiac Surgery, \\ ${ }^{3}$ Department of Physical Rehabilitation, Ergotherapy with a course of physical education, \\ ${ }^{4}$ Department of Linguistics, \\ Ivano-Frankivsk, Ukraine, \\ ORCID ID: 0000-0001-7594-5082, \\ ORCID ID: 0000-0003-2530-5276, \\ ORCID ID: 0000-0001-5418-7825, \\ ORCID ID: 0000-0003-1735-9418, \\ ORCID ID: 0000-0002-6144-2430, \\ e-mail:snizhko.tanya@bigmir.net
}

\begin{abstract}
An important component of the educational program is to ensure professional erudition, development of clinical thinking (CT), the formation of students' basic practical skills. In the year of the pandemic, it is especially difficult to really promote the development of these components of professional development in students, and modern pedagogical teaching methods, despite their effectiveness in the offline learning process, need development, improvement during distance learning. The need for the formation of CT students was determined by the founders of medicine many centuries ago, important in the creation of professional thinking was the psychological and pedagogical relationship "teacher-student-patient". Unfortunately, today this chain is lost, but the need to form analytical and exploratory thinking in medical students is extremely important, so it is necessary to revise and analyze the pedagogical methodology for modernization and use in distance learning. CT is an element of future professional activity with the help of which an algorithm of actions in specific clinical situations is created, it is the ability to identify and analyze, as well as to search and evaluate relevant information to achieve the appropriate conclusion. This article tries to conduct a conceptual analysis of the pedagogical methodology of CT formation and the possibility of their application in the conditions of distance learning of the discipline "obstetrics and gynecology". New technological programs are necessary for modeling simulation training. The main tasks of higher medical school are to achieve maximum development of intellectual abilities of the student, in the online format this can be achieved through the use of "virtual patients", situational tasks and cases, game techniques and clarity. However, methods of CT assessment and finding a strategy for its development are also important, as it is a key element of doctors' daily practice. In the 21st century, students need to think through their development, be able to work in teams, distinguish between relevant and irrelevant information from the patient, and be multilingual and highly developed so that they can be effective in all disciplines. These are the characteristics that are expected of modern medical students. However, when faced with unspecified emergencies, they are unable to make the right clinical decisions, leading to accidents. The reason for this is the lack of CT skills among young doctors, so the formation begins in school, adapting to the conditions created by the pandemic. Medical schools should teach the principles of scientific methodology and evidence-based medicine, including analytical and critical thinking, throughout the curriculum. It is important to develop a professional algorithm for the development of CT in each teacher, in order to rely on the development stimulus not only on the theoretical basis of students, but also on the ability to analyze clinical situations, and what is important to act properly algorithmically. Attention should be paid to the psychological and pedagogical aspects and approaches to the development of each student in particular. Moreover, there is no consensus on the most effective learning model for teaching CT skills and clinical considerations, and this skill is not effectively tested in medical schools, so the analysis of existing methods and their application in distance learning is extremely important.
\end{abstract}

Keywords: clinical thinking, distance learning, teaching methods.

Introduction. In modern world due to the pandemic, the issue of system of education improving in medical institutions and the formation of students' professional-system thinking with the ability to analyze, synthesize, compare and summarize the material and apply information in the right situation for a particular patient has become of great importance. Therefore, it is neces- sary to realize that high mental abilities (intelligence) are possessed by that doctor who is distinguished by depth of thinking and accuracy in diagnosis and treatment. Undoubtedly, the foundation of a high level of excellence starts in the medical cradle - alma-mater, because "Nemo mascitur capiens" ("No one is born wise") [4]. 
It should be noted that in modern conditions the peculiarities of training and requirements for specialists are radically changing, so the development of the teacher and his integration into new methods is a mandatory part of the educational process. During the pandemic, distance learning became more and more popular and new different methods of conveying educational and methodological information to higher education students of different categories are a modern necessary standard. Today, you can get almost any knowledge remotely; starting from short courses and ending with higher education, but this form of education is not suitable for everyone and not in all cases [3].

The introduction of the Bologna process involved the gradual restructuring and reform of the educational process, improving educational programs, forms and methods of teaching, monitoring and evaluation of student achievement in order to improve the quality of education [1], but it should be noted that an important part of this system is communication "Teacher-studentpatient", which, unfortunately, in terms of distance learning is partially lost, which does not allow students to fully form clinical thinking (CT).

Rationale for the study. The formation of $\mathrm{CT}$ is a complex dialectical contradictory process, mastering which is one of the most difficult and important tasks of medical education in general and the main issue of pedagogy of teachers of medical universities [6]. The peculiarity of teaching in medical universities is that for teachers, it is important not only to teach students the basic theoretical basis, but also to form the principles of professional thinking to solve standard and non-standard clinical situations in practice.

Clinical thinking is a type of productive thinking. It is always associated with the choice of the optimal solution from a number of possible options in each specific clinical situation. Thus, clinical thinking is the basis of medical practice [7]. And the importance of this skill for the student cannot be underestimated, because it creates a platform for the formation of a qualified doctor.

Clinical thinking is based on theoretical knowledge, as well as memory, imagination, intuition, skills and a high level of excellence. And the main idea of this concept is not only the solution of complex logical problems, but also the ability to observe and to establish psychological contact and trust with the patient. Modern medicine sets the task for the doctor to gain clinical experience as soon as possible. Moreover, more than 2,800 articles indexed by PubMed contain "critical thinking" in the title of the article or abstract [5]. We suggest that it is important for clinicians and patients to learn to think critically, and that teaching and learning these skills should be clearly considered. Thus, one of the foundations of pedagogical methodology in medical universities is the formation of clinical thinking as a cognitive component of professional competence. We would like to note that in the practice of the future obstetriciangynecologist and doctor of any other profession, this quality is undoubtedly very important, so the teacher's contribution to the formation of a student's productive thinking is extremely valuable.

The purpose of the article is to analyze and develop different methods of clinical thinking formation, which can be used by teachers in distance learning when teaching the subject "Obstetrics and Gynecology" in medical schools.

Materials and methods: searching, analysis and development of modern literary and scientific data that reflect the peculiarities of the formation of clinical thinking in students under distance learning conditions.

Research Results and Discussion. Clinical thinking is one of the main practical skills of an obstetrician-gynecologist, because in real life clinical cases require logical, balanced and quick actions, which are based on deep knowledge of the theoretical basis, practical skills and logical thinking.

The formation of clinical thinking is a long-term process that is created with experience, but in the educational process it is possible to create conditions to reduce the time required and prepare a young professional with professional-system thinking, it is important to use game simulation techniques, virtual patients, etc.

The peculiarity of clinical thinking is that it cannot be formed with a standard presentation of the material and testing, it is an individual skill of the practitioner. Therefore, it should be noted that it is extremely important to maintain a "student-teacher-patient" relationship, but in a pandemic, this chain is broken and requires new approaches.

First, the process of forming clinical thinking is not just a statement of the theoretical basis; it is a methodological system that combines the learning process, research qualities and analytical and exploratory direction of students' thinking to solve clinical problems. The teacher must have high knowledge of medical psychology and ethics of communication in the triangle "student teacher - patient", as well as use methods of pedagogical stimulation, educational and experimental.

The discipline "Obstetrics and Gynecology" is studied by students of the medical faculty during the $4^{\text {th }}-$ 6th year inclusively, and has 3 module controls. At the Department of Obstetrics and Gynecology named after I.D. Lanovyj at IFNMU, which provides educational services on the basis of the city clinical perinatal center, students had the opportunity to master the entire educational program and practise practical skills, both in the training center and in the hospital. However, during a pandemic, these opportunities are significantly limited, so the use of alternative remote system models of clinical thinking has become an integral part of the educational process.

One of such models, which have long been used in European countries, is the "Virtual Patient" program with various situational complex and simple clinical cases. The program "Virtual Patient" in the direction of "Obstetrics and Gynecology" was developed by Microsoft and adapted by information engineers and employees of the Department of Obstetrics and Gynecology named after I.D. Lanovyj at IFNMU for further use as part of the educational process. It should be noted that the latest computer models of patients allow the formation of logical thinking and algorithmic thinking in students online. These is a new opportunity to consolidate the knowledge gained during lectures, practical classes, selfdone work, and evaluate the quality of practical skills and structured thinking of students in a particular situation. 
This technique allows the teacher to better assess the material and is the basis for discussion of diagnostic and treatment tactics according to the proposed situation. Improving the quality and effectiveness of teaching students depends not only on the professional approach, but also on the ability to apply active teaching methods. In fact, the creation of a "virtual patient" builds an algorithm of action of each student in particular, but requires additional technical support and skills of the teacher. It is worth mentioning that we use in everyday practice also simpler methods of clinical thinking formation.

It is determined that through the use of active techniques, students remember $80 \%$ of what they said, $90 \%$ of what they did. Attention should be paid to this, namely to the use of the role-playing method and the method of situational analysis, which can be used both online and offline [5]. Creating a professional simulation game is an integral part of the daily presentation of the material, as this way of presenting the material increases the interest of students, forms the psychological readiness of future doctors to the variability of the clinical situations and helps to develop a well-thought-out algorithm in a minimum of time. There are various methods of professional simulation games that we use in everyday practice: "doctor-patient", "consultation", "ward doctor", "emergency situation". In fact, the formation of real situations in an online environment brings together contact between a teacher and students, increases the interest and enhances the amount of learnt material. This technique is simple and does not require additional technical support other than the "Virtual Patient" program. Also, professional simulation games are one-sided when all students strive to achieve the same goal.

Nowadays, during the distance learning teaching to create a professional simulation game one can use many convenient programs such as PowerPoint, Prezi, Zoho Show, PowToon and others. The development of this idea will require the teacher to contribute time and desire. However, it should be noted that the principle of clarity in the educational process of medical schools provides a link between theory and clinical reality and is one of the main elements of pedagogical practice.

The basis of a correct diagnosis is an algorithm. Each doctor, making a diagnosis, acts according to certain algorithms, which he was trained or developed himself in the course of his practice. Diagnostic algorithm (DA) is a certain sequence of mental operations and actions to diagnose those diseases that are manifested by the leading syndrome [4]. During distance learning, we tried to provide diagnostic and treatment algorithms for each student, for more effective learning.

Also, we want to note that critical thinking is not a new concept - it is a characteristic that dates back to the time of Socrates (470-399 BC) [2]. The Socratic method of teaching focuses on the question of who is learning, thought-provoking questions. Through questions and answering procedures, the teacher guides the student, through critical thinking - allows the students to test their beliefs and prejudices in order to improve understanding and solving the problem.

In recent years, all student assessment has increasingly been reduced to testing rather than oral response; although in reality tests do not provide a high percentage of memorization. According to our survey of 4 th- and $6^{\text {th }}$ - year students, it was noted that when using the test, students remembered only $35 \%$ of the information, and through the use of active learning methods, students retain in memory $87 \%$ of what they said, $90 \%$ of what they themselves considered and created according to the given task. Therefore, we want to note that active techniques are extremely effective, especially in distance learning. We recommend both to provide students with various clinical tasks and to give students the opportunity to create "their own patient" according to the topic, both in writing and orally for a limited period of time.

Healthcare professionals use critical thinking skills when they reflect on knowledge gained from other interdisciplinary subject areas in order to provide holistic health care to their patients. It is believed that the critical thinker goes through a number of cognitive stages: [1]

1. Collection of information from all senses, verbal and / or written expressions, reflections, observations, experiences and reasoning;

2. violates vital, clearly defined issues and problems;

3. collects and evaluates relevant information;

4. uses abstract ideas that are interpreted;

5. comes to reasonable conclusions and deci-

sions; standards;

6. checks the results for relevant criteria and

7. uses alternative thinking strategies according to the task / need;

8. evaluates all assumptions, consequences and practice consequences;

9. communicates effectively with others in the process of generating solutions to complex problems.

This algorithm for the formation of clinical thinking is necessary in the daily practice of the teacher as it is a part of effective learning, which involves giving students a sense of progress and control over their own learning.

This requires the teacher to create a situation where students have the opportunity to try or test their thoughts on the problem, ideally achieved by connecting students' ideas to a specific experience. Active learning involves giving students the opportunity to talk and listen meaningfully, write, read and reflect on the content, ideas, problems and issues of the academic subject. We will consider four broad categories of learning strategies that can be used during distance active learning. These are individual events, pair events, informal small groups and joint student projects. The choice will depend on the time available, the goal, and the number of students.

There is a wide range of learning strategies that help to reveal students' critical thinking, such as the concept of mapping, thought-pair-exchange strategy, brainstorming, minute article, problem-based learning, team learning, coaching, panel discussion, modeling and others. The Socratic method of teaching is the basis, as one of the target methods, which contributes to the formation of critical thinking, because it is more related to the participation of persons and is purposeful and structured. The basic concept is that students will be able to learn better if they are exposed to an active learning environ- 
ment that will also encourage students to take responsibility for their learning.

Nevertheless, we recommend combining of different pedagogical techniques to achieve the best results among students.

$\mathrm{CT}$ is an abstract concept as it is very difficult to evaluate, but it should be noted that there are developed evaluation strategies. Different assessment strategies have been proposed [3,7], and their combination is recommended to assess the accuracy of the diagnosis in relation to different content and contexts [7].

In 2018, Haring et al. identified 13 relevant subjects that were abstracted from the observed behavior of students during the study of history by expert evaluators in a qualitative study using a proved theoretical approach [4]. According to the latest scientific work, the Clinical Reasoning Indicators - History Taking Scale (CRI-HT-S) was developed based on Haring's theory.

In his study, the medical expert observed the recorded history of medical students during meetings with patients and discussed their findings [4]. These welldefined indicators of clinical reasoning consist of general and specific observable phenomena, which include contextual factors and reference systems included by evaluators. In addition, experts also viewed the scale as a guide for clinical considerations, with the opportunity to observe how well students can participate in the collection of hypothetical data during history analysis [4]. This is consistent with the theory of social perception, which assumes that evaluators use idiosyncratic pre-existing schemes based on expectations in the evaluation of students in a particular situation [3].

It should be noted that to make this assessment, the teacher must have observation and deep knowledge of psychology. During distance learning it is difficult to assess clinical thinking, due to network instability and not always good technical support, but some criteria of this assessment are easy to notice when applying situational tasks.

There are other methods of assessing clinical thinking, such as the case study method, the WatsonGlaser assessment, the Cornell Critical Thinking Test, the Critical Thinking Inventory, the California Thinking Test, and the Health Science Rationale Test. These tests help teachers and researchers to assess students' critical thinking, attitudes and reasoning $[4,7]$.

\section{Conclusions:}

1. The main component of pedagogical methods in medical universities is the formation of clinical thinking as an important cognitive component of professional competence.

2. Simulation training is an important component of the educational process during a pandemic. Simulation scenarios significantly increase the motivation and interest of students / interns to master practical skills and their ability to implement these skills in further professional activities.

3. In turn, the use of the latest technologies requires from the teacher daily self-development in programming.

4. Constant search for new pedagogical methods of teaching and improving existing ones is necessary, because a significant effect of pedagogical activities is achieved in combination and allows successfully developing professional and cultural skills, stimulating and intensifying cognitive activity of students, developing effective clinical thinking.

5. The main task of teaching is to provide psychological and pedagogical conditions that allow expanding the thinking of the student, creating a basis for correlation of the theoretical basis for solving logical and illogical clinical problems.

\section{References:}

1. American Psychological Association // ResearchSupported Psychological Treatments. 2015. Режим доступу: http://www.div12.org/psychologicaltreatments/.

2. Global minimum requirements of Medical Education.Available from: http://www.iime.org/ documents/gmer.htm

3. Gruppen LD. Clinical reasoning: defining it, teaching it, assessing it. Studying It West J Emerg Med. 2017;18:4-7.

4. Harendza S, Berberat PO, Kadmon M. Assessing competences in medical students with a newly designed 360-degree examination of a simulated first day of residency: a feasibility study. J Community Med Health Educ. 2017;7:4.

5. Hych GM. "Klipove" iuvenis cogitabat, amicus vel hostis disciplina? Continetur. Cum enim de paedagogia. 2016; 257 (269): 38-42. [Ukrainian]

6. Nacionalna dopovid pro stan i perspectuvu rozvutku osvitu v Ukraini. Nac. acad. ped. Nauk Ukrainu; za zah. red. VH Kremenia. Pedahohicna dumka; 2016. 448 s. [in Ukrainian].

7. Vanstone M, Monteiro S, Colvin E, Norman G, Sherbino J, Sibbald M, et al. Experienced physician descriptions of intuition in clinical reasoning: a typology. Diagnosis (Berl). 2019;6:259-68.

\section{УДК 378.147 .227}

\section{ОСОБЕННОСТИ ФОРМИРОВАНИЯ И ОЦЕНКИ КЛИНИЧЕСКОГО МЫШЛЕНИЯ СТУДЕНТОВ НА ДИСТАНЦИОННОМ ОБУЧЕНИИ}

Т.Б. Снижко ${ }^{1}$, В.Д. Воробий ${ }^{1}$, С.С. Снижко ${ }^{2}$, И.К. Чурпий ${ }^{3}$, Л.Я. Шпильчак ${ }^{4}$

Ивано-Франковский национальный медицинский университет:

${ }^{1}$ кафедра акушерства и гинекологии им.

И.Д. Ланового,

${ }_{2}^{2}$ кафедра хирургии и кардиохирургии,

${ }^{3}$ кафедра физической реабилитачии, эрготерапии

с курсом физического воспитания,

${ }^{4}$ кафедра языкознания,

2. Ивано-Франковск, Украина,

ORCID ID: 0000-0001-7594-5082,

ORCID ID: 0000-0003-2530-5276,

ORCID ID: 0000-0001-5418-7825,

ORCID ID: 0000-0003-1735-9418,

ORCID ID: 0000-0002-6144-2430,

e-mail: snizhko.tanya@bigmir.net 
Резюме. Важной составляющей образовательной программы является обеспечение профессиональной эрудиции, развития клинического мышления (КМ), формирование у студентов основных практических навыков. В год пандемии особенно трудно действительно способствовать развитию данных составляющих профессионального развития у студентов, а современные педагогические методы обучения, несмотря на их эффективность в офф-лайн учебном процессе, требуют развития, совершенствования во время дистанционного обучения. Необходимость формирования у студентов клинического мышления была определена основателями медицины уже много веков назад, важным в создании профессионального мышления была психологическая и педагогическая связь «преподаватель-студент-пациент». К сожалению, сегодня даная цепь потеряна, но необходимость формирования аналитико-поискового мышления у студентов медицинских вузов является чрезвычайно важной, поэтому необходим просмотр и анализ педагогической методологии для модернизации и использования их в условиях дистанционного обучения. Клиническое мышление - это элемент будущей профессиональной деятельности с помощью ее создается алгоритм действий в конкретных клинических ситуациях, это способность идентифицировать и анализировать, а также искать и оценивать соответствующую информацию для достижения соответствующего заключения. Эта статья пытается провести концептуальный анализ педагогической методологии формирования критического мышления и возможность применения их в условиях дистанционного обучения дисциплины «акушерство и гинекология». Новые технологические программы необходимы для моделирования симуляционных кейсов. Основными задачами высшей медицинской школы является достижение максимального развития интеллектуальных способностей студента, в онлайн формате этого можно достичь благодаря использованию методов «виртуальный пациент», ситуационных задач и кейсов, игровые методики и наочность.

Ключевые слова: клиническое мышление, дистанционное обучение, методики преподавания.

\section{УДК 378.147.227}

\section{ОСОБЛИВОСТІ ФОРМУВАННЯ ТА ОЦІНКИ КЛІНІЧНОГО МИСЛЕННЯ У СТУДЕНТІВ НА ДИСТАНЦІЙНОМУ НАВЧАННІ}

\author{
Т.Б. Сніжко ${ }^{1}$, В.Д. Воробій ${ }^{1}$, С.С. Сніжко ${ }^{2}$,
} І.К. Чурпій ${ }^{3}$, Л.Я. Шпільчак ${ }^{4}$

Івано-Франківський національний медичний університет:

${ }^{1}$ кафедра акушерства та гінекологіі

ім. І.Д. Ланового,

${ }^{2}$ кафедра хірургї̈ та кардіохірургї,

${ }^{3}$ кафедра фізичної реабілітації, ерготерапії з курсом фізичного виховання,

${ }_{4}^{4}$ кафедра мовознавства,

м. Івано-Франківськ, Україна,

ORCID ID: 0000-0001-7594-5082,

ORCID ID: 0000-0003-2530-5276,

ORCID ID: 0000-0001-5418-7825,

ORCID ID: 0000-0003-1735-9418,

ORCID ID: 0000-0002-6144-2430,

e-mail: snizhko.tanya@bigmir.net

Резюме. Важливою складовою освітньої програми є забезпечення професійної ерудиції, розвитку клінічного мислення (КМ), формуванню у студентів основних практичних навичок. В рік пандемії особливо важко справді посприяти розвитку даних складових професійного розвитку в студентів, а сучасні педагогічні методи навчання, незважаючи на їхню ефективність в оф-лайн навчальному процесі, потребують розвитку, вдосконалення в час дистанційного навчання. Необхідність формування в студентів клінічного мислення було визначено основоположниками медицини вже багато століть назад, важливим у створенні професійного мислення був психологічнопедагогічний зв'язок «викладач-студент-пацієнт». На жаль, сьогодні даний ланцюг втрачено, але необхідність формування аналітико-пошукового мислення в студентів медичних вузів $є$ надзвичайно важливою, тому необхідний перегляд та аналіз педагогічної методології для модернізації та використання їх в умовах дистанційного навчання. Клінічне мислення - це елемент майбутньої професійної діяльності за допомогою ऑï створюється алгоритм дій в конкретних клінічних ситуаціях, це здатність ідентифікувати та аналізувати, а також шукати та оцінювати відповідну інформацію для досягнення відповідного висновку. Ця стаття намагається провести концептуальний аналіз педагогічної методології формування критичного мислення та можливість застосування їх в умовах дистанційному навчанні дисципліни «акушерство та гінекологія». Нові технологічні програми є необхідними для моделювання симуляційного навчання. Основними завданнями вищої медичної школи є досягнення максимального розвитку інтелектуальних здібностей студента, в онлайн форматі цього можливо досягти завдяки використанню методів «віртуальних пацієнтів», ситуаційних задач та кейсів, ігрові методики та наочності.

Ключові слова: клінічне мислення, дистанційне навчання, методики викладання. 